\title{
Peningkatan literasi dan keahlian perbankan pada masyarakat pra kerja melalui simulasi mini bank dan praktik hitung uang 3 jari
}

\author{
Y Rahmat Akbar ${ }^{(\mathbb{D}) * 1}$ \& Yayu Kusdiana ${ }^{2}$ \\ 'Sekolah Tinggi Ilmu Ekonomi Persada Bunda, Indonesia \\ 2Sekolah Tinggi Ilmu Ekonomi Mahaputra, Indonesia \\ *yrahmat.akbar@stiepersadabunda.ac.id
}

\begin{abstract}
In the face of industrial development in the industrial revolution era 4.0, the need for reliable preparation of Human Resources, so that no less competitive with the rapid growth of information and technology. Community service activities are carried out with themes by the latest developments in the industrial world aimed at the pre-employment community as participants to have theoretical and applicable knowledge, insights and expertise in the banking sector. The method of this activity is in the form of training with a mini bank simulation and the practice of counting money using 3 fingers. Participants are given knowledge in the world of banking and are guided to practice some basic skills that must be possessed by a banker. This activity involves academics and practitioners in the field of banking. From the results of the training provided, the achievement of the objectives of service activities can be seen from the understanding of participants in explaining some of the terms of funds, credit, other bank services and bank work systems as well as the ability of participants to simulate work at the bank. With this knowledge and expertise, it is expected to create human resources who are ready to work in banking and reduce the unemployment rate.
\end{abstract}

\begin{abstract}
Abstrak Dalam menghadapi perkembangan industri di era revolusi industri 4.0, perlunya persiapan Sumber Daya Manusia yang handal, sehingga tidak kalah bersaing dengan pertumbuhan informasi dan teknologi yang begitu pesat. Kegiatan pengabdian pada masyarakat ini dilakukan dengan tema yang sesuai dengan perkembangan terkini dunia industri yang ditujukan kepada masyarakat pra kerja sebagai peserta agar memiliki pengetahuan, wawasan dan keahlian di sektor perbankan secara teoritis dan aplikatif. Metode kegiatan ini berupa pelatihan dengan simulasi mini bank serta praktik menghitung uang dengan menggunakan 3 Jari. Peserta diberikan pengetahuan dalam dunia perbankan dan dibimbing untuk mempraktikkan beberapa keahlian dasar yang harus dimiliki oleh seorang bankir. Kegiatan ini melibatkan akademisi dan praktisi di bidang perbankan. Dari hasil pelatihan yang diberikan, ketercapaian tujuan kegiatan pengabdian dilihat dari pemahaman peserta dalam menjelaskan beberapa istilah dana, kredit, jasa bank lainnya dan sistem kerja bank serta kemampuan peserta dalam mensimulasikan pekerjaan di bank. Dengan pengetahuan dan keahlian yang dimiliki tersebut diharapkan mampu menciptakan sumber daya manusia yang siap kerja pada perbankan dan mengurangi tingkat pengangguran.
\end{abstract}

Keywords: training; simulation; banking; pre-employment; industry 4.0; service excellent

\section{Ә OPEN ACCESS}

Citation: Akbar, Y.R., \& Kusdiana, Y. (2020). Peningkatan literasi dan keahlian perbankan pada masyarakat pra kerja melalui simulasi mini bank dan praktik hitung uang 3 jari. Riau Journal of Empowerment, 3(3), 139-148. https://doi.org/10.31258/raje.3.3.139-148

Paper type: Community service

Received: 2020-07-04 Revised: 2020-08-20 Accepted: 2020-08-23

Language: Bahasa Indonesia (id) ISSN 2623-1549 (online), 2654-4520 (print)

(c) 2020 Y Rahmat Akbar \& Yayu Kusdiana. Author(s) retain the copyright of article published in this journal, with first publication rights granted to Riau Journal of Empowerment. The article is licenced under Creative Commons Attribution 4.0 International License. This license permits unrestricted use, distribution, and reproduction in any medium, provided the original author and source are credited. 


\section{PENDAHULUAN}

Kemajuan teknologi telah mengubah wajah perekonomian, khususnya di sektor industri dan perdagangan, termasuk sektor keuangan. Salah satu fase penting dalam perkembangan teknologi adalah munculnya revolusi industri 4.0 yang memiliki efek terhadap kelangsungan hidup manusia (Mekinjić, 2019). Perubahan ini tentunya akan menyebabkan berkurangnya jumlah tenaga kerja, karena pemanfaatan digitalisasi dan robotika akan membuat semakin tingginya tingkat efisiensi dan efektivitas kerja. Diprediksikan revolusi industri ini akan menghilangkan 800 juta lapangan pekerjaan yang saat ini ada di dunia (Dalimunte et al., 2018). Proses revolusi industri menjadi ancaman bagi negara Indonesia disebabkan karena pengambilalihan pekerjaan oleh robot dan pemanfaatan yang menyeluruh pada proses digitalisasi sampai tahun 2030 (Hartati, 2020). Indonesia yang saat ini memiliki angkatan kerja dalam jumlah besar namun juga memiliki tingkat pengangguran yang tinggi pula (Handayani, 2015). Pentingnya pemahaman akan lingkungan teknologi berubah menjadi sebuah tuntutan untuk mempersiapkannya, hampir semua profesi yang ada saat ini terdampak baik langsung maupun tidak langsung (Marsudi \& Widjaja, 2019).

Di sisi lain, bentuk baru kebutuhan tenaga kerja harus memiliki karakteristik yang mampu menyinergikan akan pengalaman dan prestasi dengan memanfaatkan teknologi sehingga dapat mengeksploitasi teknologi untuk dapat mempromosikan diri, memiliki kemampuan dalam mendemonstrasikan kemampuan yang ada dengan peralatan berteknologi tinggi dan memiliki kemampuan untuk melakukan evaluasi atas berbagai perubahan lingkungan yang terus berkembang dengan memanfaatkan kemampuan kritis akan perubahan teknologi (Malik, 2019). Keniscayaan digitalisasi perbankan, mustahil tanpa kebutuhan Sumber Daya Manusia (SDM). Hanya saja di era ini, tenaga kerja yang dibutuhkan akan lebih kompleks dari sebelumnya. Dalam hal ini tenaga kerja yang ada tetap merupakan faktor penting. Namun bila tenaga kerja yang digunakan memiliki kemampuan terbatas maka produktivitas yang dihasilkan juga akan terbatas.

Oleh sebab itu, kemajuan teknologi di dunia perbankan harus dapat diimbangi oleh sumber daya yang memiliki kemampuan yang handal dari segi pengetahuan maupun keahlian (Alam et al., 2019). Hal ini dikarenakan untuk menciptakan kepuasan dan retensi nasabah bank masih diperlukan peranan manusia dalam meningkatkan layanan maupun produk perbankan (Akbar, 2014). Kualitas layanan dan produk sebagai bagian dari dimensi service marketing mix ini tidak hanya berlaku pada bank konvensional namun juga pada perbankan syariah (Akbar et al., 2019). Dengan adanya tenaga kerja yang terampil dan memiliki literasi yang baik di bidang perbankan menjadi bagian dari pemasaran terintegrasi bagi bank (Akbar \& Elsye, 2019), sehingga diharapkan dapat menciptakan keunggulan bersaing Indonesia di sektor perbankan.

Kota Pekanbaru merupakan salah satu kota yang memiliki perkembangan industri perbankan cukup pesat. Banyaknya kantor bank yang ada di kota Pekanbaru saat ini, telah berjumlah 1.483 kantor yang terdiri dari 18 kantor pusat, 1 kantor wilayah, 58 kantor cabang, 120 kantor cabang pembantu, 82 kantor kas, dan 1.204 kantor lainnya. Berdasarkan kepemilikan bank umum pemerintah yang beroperasi di Pekanbaru sebanyak 863 kantor, Bank Swasta sebanyak 598 kantor, dan Bank Perkreditan Rakyat sebanyak 22 kantor (Otoritas Jasa Keuangan, 2019). Dengan jumlah penduduk sebanyak 954.273 jiwa pada tahun 2019, masalah penduduk tidak terlepas dari masalah ketenagakerjaan. Jika tingkat pertumbuhan penduduk tinggi maka seharusnya penyediaan tenaga kerja juga luas. Penawaran kerja yang tinggi tanpa diimbangi dengan kualitas sumber daya yang memadai akan menimbulkan pengangguran. Saat ini, Tingkat Partisipasi Angkatan Kerja (TPAK) di kota Pekanbaru tahun 2019 sebesar 
66,12 dengan tingkat pengangguran sebesar 7,86. Artinya dari 100 penduduk usia kerja, hanya 66 orang diantaranya berpartisipasi aktif di dunia kerja, dan sisanya sebesar 7,86 persen dari jumlah angkatan kerja adalah pengangguran (Badan Pusat Statistik Kota Pekanbaru, 2020).

Berbagai pelatihan kerja yang diberikan oleh pemerintah kota Pekanbaru baik dengan dana APBD maupun APBN, terus dilakukan dalam upaya menekan angka pengangguran. Pelaksanaan pelatihan dilakukan secara institusional dan non institusional. Namun pelatihan ini lebih banyak pada lingkup teknik seperti operator komputer, instalasi listrik, mobil bensin, meubeler, dan menjahit. Sedangkan pelatihan lingkup bisnis manajemen hanya sekretaris dan administrasi. Banyaknya tenaga kerja asing yang bekerja pada perusahaan di Pekanbaru juga menambah tantangan bagi tenaga kerja lokal untuk dapat bersaing di dunia kerja (Badan Pusat Statistik Kota Pekanbaru, 2020).

Perubahan industri yang sangat cepat ini perlu diantisipasi dengan respons dan adaptasi yang cepat dari pihak-pihak terkait. Oleh karena itu, upaya yang dapat dilakukan dalam mengatasi permasalahan secara umum di Indonesia yaitu mendorong masyarakat untuk terus belajar diiringi peningkatan keahlian dan keterampilan dengan mengintegrasikan penggunaan teknologi (Fadli et al., 2019). Memiliki daya saing merupakan hal yang vital bagi sumber daya manusia di sektor perbankan dikarenakan identik dengan kemajuan teknologi (Zain \& Akbar, 2020). Hal ini juga yang menyebabkan masih tingginya minat untuk masyarakat untuk berkarir pada sektor perbankan (Mashadi \& Irawan, 2017). Berdasarkan permasalahan tersebut, maka perlu diberikan suatu edukasi berupa pelatihan yang bertujuan meningkatkan kemampuan masyarakat dalam memahami proses dan prosedur di bank serta memiliki keahlian yang mengimbangi kemajuan teknologi di sektor keuangan. Pelaksanaan pengabdian masyarakat ini diharapkan dapat menciptakan sumber daya manusia yang siap kerja dan memiliki added value di bidang perbankan karena sudah dibekali dengan pengetahuan dan wawasan tentang perbankan secara teoritis dan aplikatif (Cotet et al., 2017).

Secara umum target dan sasaran dari kegiatan pengabdian kepada masyarakat ini adalah masyarakat pra kerja khususnya warga kota Pekanbaru yang memiliki keinginan atau berminat untuk berkarir pada industri perbankan. Pemilihan dan penetapan sasaran pelatihan ini mempunyai pertimbangan rasional-strategis dalam kaitannya dengan upaya pemberian keahlian dan skill dengan praktik simulasi kerja di bank. Kegiatan pelatihan ini merupakan bentuk peningkatan literasi masyarakat di bidang perbankan dalam menghadapi persaingan di dunia kerja dengan tantangan perkembangan industri.

\section{METODE PENERAPAN}

Metode kegiatan pengabdian kepada masyarakat ini berupa pelatihan dengan model simulasi mini bank dan praktik hitung uang 3 jari. Peserta dibimbing untuk menerapkan hasil pelatihan dalam rangka meningkatkan pengetahuan dan keahlian peserta dalam bidang perbankan. Berikut ini adalah tahapan pengabdian kepada masyarakat yang dilakukan:

\section{Tahap Persiapan}

Sebelum diadakannya pelatihan, dilakukan company visit dengan cara diskusi bersama dengan tim termasuk praktisi dari pihak perbankan berkaitan dengan tema, penentuan lokasi, sasaran, waktu pelaksanaan dan perlengkapan yang dibutuhkan untuk kelancaran pelaksanaan pelatihan. Kemudian menyiapkan segala kebutuhan dalam pelaksanaan pelatihan termasuk 
pembuatan materi. Selanjutnya menambah materi dan praktik studi kasus yang dapat meningkatkan pengetahuan dan kemampuan peserta dari beberapa pekerjaan yang masih di aplikasikan di dunia perbankan.

\section{Tahap Penyuluhan (Knowledge Sharing)}

Dalam tahap ini dilakukan penjelasan dari akademisi dan praktisi bank tentang perkembangan industri 4.0, pentingnya financial technology (fintech) dan literasi beberapa teori perbankan. Sesi ini menitikberatkan pada pemberian penjelasan operasional bank (funding, lending dan jasa bank lainnya) dan bagaimana sistem bank bekerja. Penyuluhan ini bertujuan untuk menambah literasi peserta dan memberikan informasi tentang perkembangan perbankan. Di akhir kegiatan sesi ini, setiap peserta pelatihan diberi kesempatan untuk bertanya dan berdiskusi tentang materi yang telah disajikan oleh para narasumber.

\section{Tahap Tutorial (Simulasi)}

Setelah memberikan materi dari narasumber, kegiatan selanjutnya dilakukan tutorial dengan simulasi mini bank yaitu praktik service excellent dan cara cepat menghitung uang dengan menggunakan 3 jari. Metode pelaksanaannya menggunakan metode tutorial dengan cara mencontohkan dan meminta para peserta untuk maju ke depan untuk mempraktikkannya.

Dalam pelatihan ini juga diberikan materi beserta case agar peserta pelatihan bisa benarbenar memahami kondisi lapangan di dunia perbankan dan juga memiliki kemampuan dasar dalam praktik kerja langsung di bank. Kemampuan dan pengetahuan dasar serta pemberian skill praktik kerja bank ini diharapkan mampu meningkatkan nilai tambah tersendiri bagi peserta pelatihan, terutama pada peserta yang sedang mencari pekerjaan dan berminat bekerja di bank.

\section{Metode Evaluasi}

Adapun indikator keberhasilan dalam evaluasi dilakukan dengan 2 metode, yaitu:

1. Evaluasi selama proses kegiatan Evaluasi saat pelaksanaan pelatihan dilihat dari kemampuan dan keterlibatan peserta pada setiap tahap pelatihan. Pada tahap akhir, peserta diharapkan dapat memahami beberapa jenis pekerjaan pada bank dengan mengaplikasikan menghitung uang dengan menggunakan uang 3 jari dan mempraktikkan pelayanan prima (service excellent).

2. Evaluasi pasca kegiatan keberhasilan kegiatan pengabdian masyarakat ini dilihat berdasarkan taraf penyelesaian materi pelatihan dengan memberikan reward kepada para peserta pelatihan yang dapat menjawab pertanyaan-pertanyaan (berupa games) dan dapat berhasil menghitung uang menggunakan 3 jari dengan cepat.

Alat ukur ketercapaian kegiatan pengabdian kepada masyarakat ini adalah minimal 50\% peserta pelatihan mengalami peningkatan pemahaman mengenai dunia perbankan. Ini diukur secara kuantitatif melalui pre-test dan post-test yang akan diberikan sebelum dan setelah pemberian materi. 
HASIL DAN KETERCAPAIAN SASARAN

Kegiatan pengabdian kepada masyarakat dalam bentuk pelatihan ini dilaksanakan di Ballroom Hotel Amera, Central Plaza Pekanbaru. Jumlah peserta sebanyak 137 orang yang terdiri dari masyarakat umum, mahasiswa, akademisi dan praktisi perbankan dengan distribusi komposisi peserta yang dapat dilihat pada Tabel 1 .

Tabel 1. Komposisi Peserta Pelatihan

\begin{tabular}{|c|c|c|c|}
\hline Variabel & Karakteristik & Frekuensi & Persentase (\%) \\
\hline \multirow[t]{2}{*}{ Jenis Kelamin } & Laki-laki & 53 & 38,6 \\
\hline & Perempuan & 84 & 61,3 \\
\hline \multirow[t]{6}{*}{ Usia } & dibawah 21 tahun & 9 & 6,57 \\
\hline & 21 tahun sampai dengan 30 & 108 & 78,8 \\
\hline & tahun & 12 & 8,76 \\
\hline & $\begin{array}{l}31 \text { tahun sampai dengan } 40 \\
\text { tahun }\end{array}$ & 8 & 5,84 \\
\hline & $\begin{array}{l}41 \text { tahun sampai dengan } 50 \\
\text { tahun }\end{array}$ & - & - \\
\hline & diatas 50 tahun & & \\
\hline \multirow[t]{4}{*}{ Pendidikan } & SMA Sederajat & 52 & 37,9 \\
\hline & Akademi/Diploma & 45 & 32,8 \\
\hline & Sarjana & 31 & 22,6 \\
\hline & Pascasarjana & 9 & 6,57 \\
\hline \multirow[t]{4}{*}{ Pekerjaan } & Mahasiswa & 69 & 50,3 \\
\hline & Dosen & 6 & 4,38 \\
\hline & Praktisi Perbankan & 5 & 3,65 \\
\hline & Masyarakat Umum & 57 & 41,6 \\
\hline
\end{tabular}

Berdasarkan Tabel 1 dapat dilihat bahwa dominasi peserta dengan jenis kelamin perempuan. Ini menunjukkan perempuan yang paling banyak memiliki minat untuk berkarir di bank. Adapun rentang umur peserta pelatihan mayoritas pada usia 21 tahun sampai dengan usia 30 tahun. Rentang usia tersebut berada pada usia produktif yang sudah cukup umur untuk dapat bekerja. Untuk tingkat pendidikan peserta mayoritas Sederajat Sekolah Menengah Atas, Diploma dan sarjana. Sedangkan pekerjaan peserta di dominasi oleh mahasiswa dan masyarakat umum. Hal ini sesuai dengan target dan sasaran dari kegiatan pengabdian kepada masyarakat ini yaitu masyarakat pra kerja yang belum bekerja dan memiliki keinginan atau berminat untuk berkarir pada industri perbankan. Pemilihan dan penetapan sasaran pelatihan ini mempunyai pertimbangan agar dapat menekan tingkat pengangguran dengan upaya pemberian pengetahuan/literasi, keahlian dan skill dengan praktik simulasi kerja di bank, sehingga masyarakat pra kerja memiliki nilai tambah dan daya saing dalam menghadapi persaingan di dunia kerja dan tantangan perkembangan industri. 
Pada sesi knowledge sharing, para peserta pelatihan di awal materi diberikan pertanyaan seputar pemahaman mereka tentang operasional bank, apa perlunya Financial Technology (FinTech) di dunia perbankan, kenapa perlu peningkatan life skill, kenapa saat ini penting memahami digitalisasi di berbagai sektor khususnya dunia Perbankan.

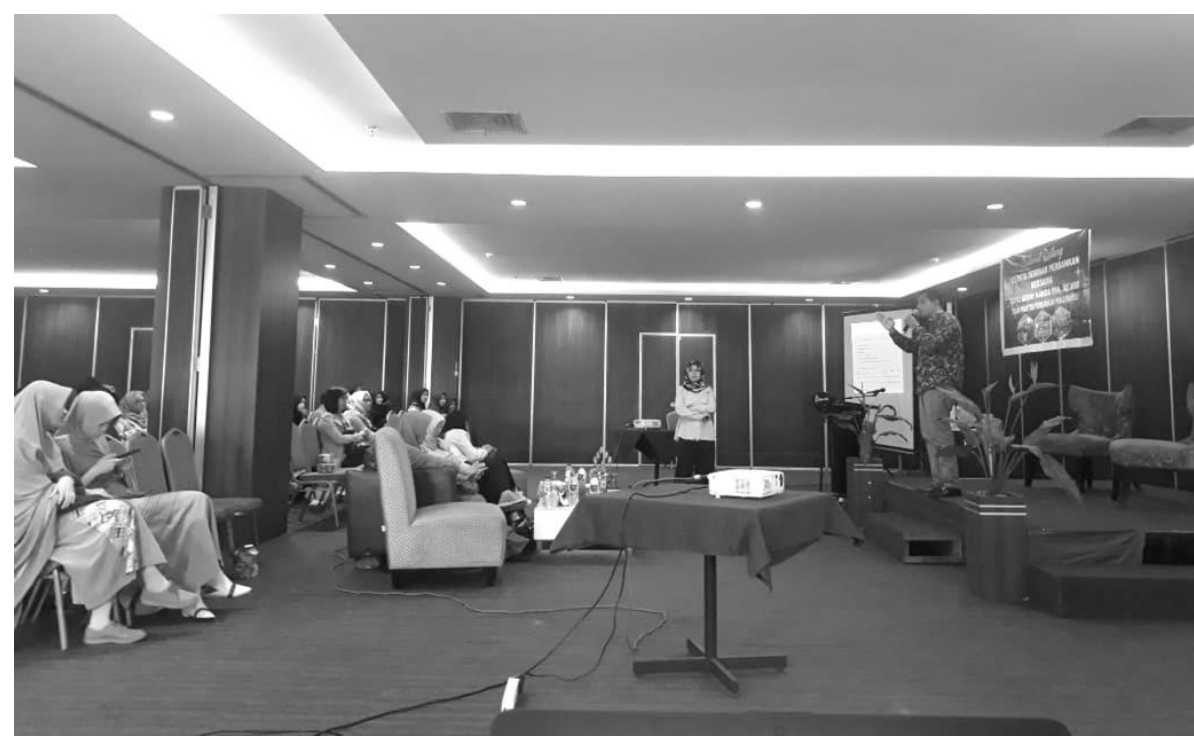

Gambar 1. Penyampaian materi konsep-konsep dasar dan beberapa case perbankan

Kegiatan dilaksanakan secara bertahap dari pemaparan konsep-konsep dasar perbankan yang dilanjutkan beberapa case yang perlu diketahui terkait pengetahuan, kemampuan dan keahlian dasar yang harus dimiliki oleh seorang bankir. Kegiatan pemaparan materi tersebut dapat dilihat pada Gambar 1. Peserta mengikuti kegiatan dinilai antusias ditunjukkan dengan pertanyaan-pertanyaan dan beberapa tanggapan dari peserta mengenai materi yang diberikan.

Secara umum pertanyaan peserta mengenai beberapa fenomena sebagai berikut:

1. Perbandingan bank konvensional dan bank syariah

2. Mewaspadai informasi teknologi digital dalam memanfaatkan jasa internet/online/mobile banking

3. Pinjaman online (financial technology)

4. Bisnis digital (e-commerce) dan dukungan perbankan

5. Model jasa perbankan masa depan.

Dilakukan test tanya jawab untuk menguji sejauh mana tingkat pengetahuan peserta pelatihan terhadap materi yang akan disampaikan. Diharapkan adanya peningkatan pengetahuan peserta pelatihan. Untuk lebih memperdalam kembali pemahaman peserta, para narasumber kembali memberikan kesempatan kepada peserta pelatihan untuk memberikan pertanyaan dan mendiskusikan kembali letak ketidakpengetahuan peserta, mendiskusikan permasalahan-permasalahan yang selama ini mereka alami, setelah itu narasumber memberikan jawaban atas pertanyaan tersebut dan memberikan solusi atas permasalahan yang dialami oleh peserta seminar.

Untuk mengukur tingkat literasi peserta telah disiapkan 30 pertanyaan yang ada dalam kuesioner terkait dengan sistem kerja dan operasional bank yang terdiri dari funding, lending dan jasa bank lainnya, kemudian juga beberapa soal terkait perkembangan perbankan dalam 
financial technology. Setiap peserta diminta untuk mengisi dan memberikan jawaban dari 30 pertanyaan di awal pelatihan dan nantinya di akhir pelatihan dengan soal yang sama. Hasil test secara rata-rata kemampuan dasar peserta pelatihan perbankan yang diuji pada awal dan akhir kegiatan pengabdian dapat dilihat pada Gambar 2.

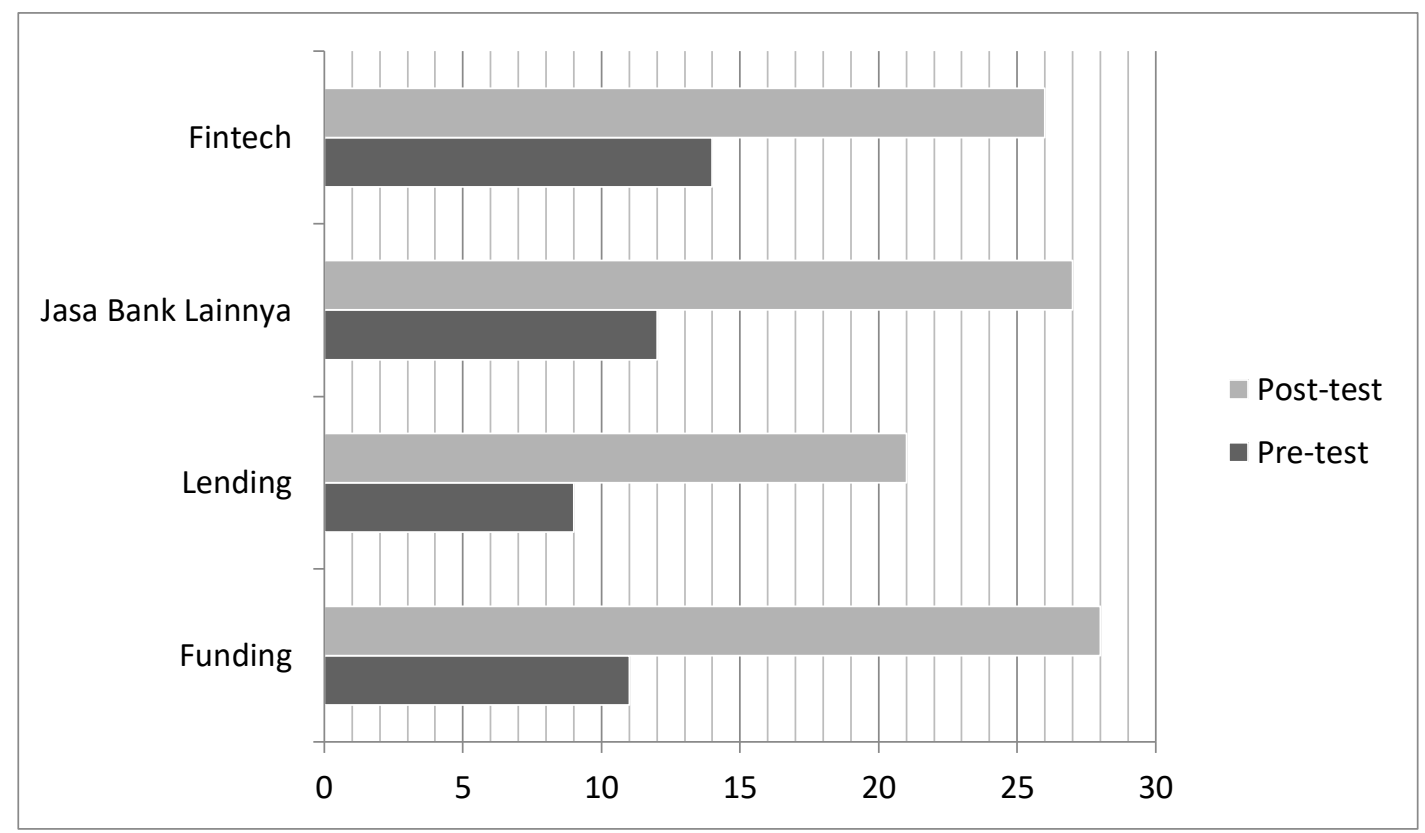

Gambar 2. Hasil test kemampuan dasar (rata-rata) peserta pelatihan perbankan yang diuji pada awal dan akhir kegiatan pengabdian.

Berdasarkan hasil test kemampuan dasar peserta pelatihan perbankan, menunjukkan peningkatan pengetahuan peserta dari sebelum dilakukannya pelatihan (pre-test) dan setelah dilakukannya pelatihan (post-test). Peningkatan ini menunjukkan hasil yang positif karena secara rata-rata peserta dapat menjawab dengan benar lebih dari setengah soal pertanyaan yang diberikan. Jawaban pada soal pertanyaan mengenai dana bank (funding) mengalami peningkatan $57 \%$ dari $36 \%$ menjadi $93 \%$ soal yang terjawab. Untuk soal pertanyaan mengenai kredit bank (lending) mengalami peningkatan $40 \%$ dari $30 \%$ menjadi $70 \%$ soal yang terjawab. Demikian juga pada soal pertanyaan mengenai jasa bank lainnya. Peningkatan soal yang mampu dijawab peserta sebesar $50 \%$ dari $40 \%$ menjadi $90 \%$. Pada soal pertanyaan mengenai financial technology mengalami peningkatan $40 \%$ dari $47 \%$ menjadi $87 \%$ soal yang mampu dijawab peserta.

Kegiatan penyuluhan dalam pelatihan perbankan ini dilaksanakan dengan metode diskusi dan sharing atas beberapa studi kasus yang ada di dunia perbankan. Pertemuan ini diberikan dengan konsep pelatihan diskusi yang disertai contoh-contoh case yang ada di lapangan. Selain menambah wawasan bagi peserta, pengetahuan dan studi kasus yang diberikan juga sebagai bekal bagi peserta agar tidak canggung apabila nantinya berada pada dunia kerja perbankan yang sebenarnya karena telah memiliki dasar literasi yang baik dari pelatihan yang diikuti.

Setelah kegiatan penyuluhan, kegiatan dilanjutkan dengan beberapa praktik kerja kantoran di perbankan dengan metode tutorial. Metode tutorial menggunakan model simulasi mini bank. Pelaksanaan praktik kerja di bank ini lebih banyak dalam bidang front liner yang dilakukan dengan pokok bahasan yang disampaikan mengenai Praktik Hitung Uang 3 Jari dan Pelayanan Prima (service excellent). Karena bank merupakan perusahaan yang bergerak di 
bidang jasa maka pelayanan merupakan hal yang utama dan wajib diketahui. Praktik hitung uang merupakan dasar kemampuan operasional bagi teller/kasir. Dengan kemampuan hitung uang 3 jari, peserta akan mampu melayani nasabah dengan cepat. Sedangkan dengan tutorial pelayanan prima (service excellent) merupakan kemampuan operasional bagi customer service dan secara umum bagi pegawai bank. Dengan simulasi minibank ini peserta mampu mempraktikkan pelayanan nasabah dengan baik dan teknik-teknik dalam menangani komplain/keluhan nasabah. Hal ini dimaksudkan agar peserta memiliki bekal dasar keahlian sebagai calon pegawai bank.

Rancangan evaluasi dilakukan selama proses tutorial, pada aspek pencapaian tujuan pelatihan dan juga penyelenggaraan pelatihan. Evaluasi proses dan hasil (pencapaian tujuan kegiatan pengabdian) menggunakan praktik simulasi, tanya jawab serta observasi.

Kegiatan pengabdian ini dinilai terlaksana sesuai dengan sasaran yang diharapkan. Ketercapaian sasaran ini dilihat dari kemampuan sebagian besar peserta dalam memahami materi dengan baik yang ditunjukkan kemampuan dan antusias dari peserta dalam mengikuti pelatihan. Selain itu ketercapaian juga dilihat dari peningkatan hasil yang positif karena secara rata-rata peserta dapat menjawab dengan benar lebih dari setengah soal pertanyaan $(>50 \%)$ yang diberikan dari evaluasi pre-test dan post-test. Peserta juga mampu menjawab dengan baik setiap pertanyaan-pertanyaan dalam kuis yang diberikan oleh pelaksana kegiatan. Hal ini menandakan peningkatan literasi pada peserta setelah mengikuti pelatihan. Begitu juga dengan simulasi yang dilakukan dengan tutorial. Evaluasi kegiatan tutorial menggunakan praktik simulasi, tanya jawab serta observasi. Peserta sudah mampu mempraktikkan cara menghitung uang dengan menggunakan 3 jari dan teknik melayani nasabah serta cara mengelola keluhan nasabah dengan baik.

Secara keseluruhan peserta puas dengan kegiatan pelatihan yang telah dilaksanakan, peserta merasa terbantu karena pelatihan ini bagian dari kompetensi yang diharapkan dalam menghadapi tantangan di dunia kerja. Sebagian peserta yang merasa antusias mengikuti kegiatan juga memberikan saran untuk diadakannya kegiatan pelatihan lanjutan dengan waktu pelatihan yang lebih lama, serta kelanjutan program pelatihan untuk praktik lanjutan.

\section{KESIMPULAN}

Perkembangan industri di sektor perbankan menyebabkan perlunya untuk mempersiapkan Sumber Daya Manusia yang unggul, seiring dengan perubahan teknologi yang semakin pesat. Dengan adanya kegiatan pengabdian dapat menciptakan sumber daya manusia yang siap kerja dan memiliki added value di bidang perbankan karena sudah dibekali dengan pengetahuan dan wawasan tentang perbankan secara teoritis dan aplikatif. Kegiatan pelatihan ini merupakan bentuk peningkatan literasi masyarakat di bidang perbankan dalam menghadapi persaingan di dunia kerja dengan tantangan perkembangan industri.

Kegiatan ini terlaksana sesuai dengan sasaran yang diharapkan dilihat dari pemahaman para peserta dalam memahami materi dan kemampuan menjawab test yang diberikan. Kegiatan ini juga tidak terlepas dari kelemahan. Di sisi waktu yang relatif pendek, membuat beberapa materi yang diberikan harus dipadatkan, sehingga hanya dapat memberikan beberapa pengetahuan dan keahlian dasar. Namun secara umum pelatihan sekaligus merupakan program pengabdian masyarakat yang sudah terlaksana ini, dapat memberikan pemahaman dan juga kemampuan peserta dalam bidang perbankan yang akan berdampak pada peningkatan literasi 
dan skill peserta, sehingga dapat diterima bekerja pada industri perbankan dan secara tidak langsung akan mengurangi tingkat pengangguran.

Akbar \&

Kusdiana

Dari evaluasi kegiatan pengabdian yang dilakukan, pelaksanaan praktik yang dilakukan dalam kegiatan pengabdian ini lebih banyak dalam bidang front liner yang dilakukan dengan tutorial mengenai Praktik Hitung Uang 3 Jari dan Pelayanan Prima (service excellent). Oleh karena itu disarankan untuk kegiatan pengabdian lanjutan dapat dilakukan dengan materi perbankan bidang yang lain seperti treasury, manajemen risiko kredit, legal banking, atau yang sesuai antusias dari peserta dengan konsekuensi penambahan waktu pelaksanaan dan biaya yang mengikuti kegiatan.

\section{UCAPAN TERIMA KASIH}

Dalam pelaksanaan kegiatan pengabdian kepada masyarakat ini, ucapan terima kasih kepada Pimpinan beserta panitia pelatihan Lembaga Pendidikan Bina Sukses Indonesia atas kerjasamanya dan permintaannya kepada kami untuk menjadi salah satu narasumber, Lembaga Penelitian dan Pengabdian Masyarakat Yayasan Pendidikan Persada Bunda dan STIE Mahaputra yang memberikan dukungannya dalam kegiatan pengabdian kepada masyarakat ini serta seluruh peserta yang antusias mengikuti kegiatan ini

\section{Daftar Pustaka}

1. Akbar, Y.R. (2014). Pengaruh Bauran Pemasaran Jasa Terhadap Kepuasan dan Retensi Nasabah Tabungan Pada Bank Nagari Cabang Pekanbaru. Jurnal Tepak Manajemen Bisnis, 6(1), 105113, 105-113. https://jtmb.ejournal.unri.ac.id/index.php/JTMB/article/view/2379

2. Akbar, Y.R., \& Elsye, M.A. (2019). Pemasaran Terintegrasi Untuk Meningkatkan Minat Masyarakat dalam Menabung di Bank Syariah. Jurnal ISLAMIKA, 2(2), 82-97. https://doi.org/10.37859/jsi.v2i2.1638

3. Akbar, Y.R., Zain, I., \& Nuraini, P. (2019). Analisis Dimensi Service Marketing Mix Sebagai Pengukur Kepuasan Nasabah Bank Syariah di Pekanbaru. Jurnal Tabarru': Islamic Banking and Finance, 2(2), 1-15. https://doi.org/10.25299/jtb.2019.vol2(2).4395

4. Alam, T.G., Antony, A.L., Hotama, K.V., \& Kuswandi, S.S. (2019). Revolusi Industri Keempat: Akhir dari Buruh di Seluruh Dunia. Jurnal Hubungan Internasional, 12(2), 33-48. https://doi.org/10.20473/jhi.v12i2.13311

5. Badan Pusat Statistik Kota Pekanbaru. (2020). Kota Pekanbaru Dalam Angka. Badan Pusat Statistik Kota Pekanbaru.

6. Cotet, G.B., Balgiu, B.A., \& Zaleschi, V.C. (2017). Assessment procedure for the soft skills requested by Industry 4.0. MATEC web of conferences, 121, Article 07005. http://doi.org/10.1051/matecconf/201712107005

7. Dalimunte, R.P., Paramita, H., \& Adilla, S. (2018). Tantangan Komunikasi Baru Digital dan Revolusi Industri 4.0. Prosiding Konferensi Nasional Komunikasi, 2(01), 789-794. http://pknk.web.id/index.php/PKNK/article/view/212

8. Fadli, R.P., Mudjiran, M., Ifdil, I., \& Amalianita, B. (2019). Peluang dan tantangan bimbingan karir di sekolah menengah kejuruan pada era revolusi industri 4.0. Jurnal EDUCATIO: Jurnal Pendidikan Indonesia, 5(2), 102-108. https://doi.org/10.29210/120192395

9. Handayani, T. (2015). Relevansi lulusan perguruan tinggi di Indonesia dengan kebutuhan tenaga kerja di era global. Jurnal Kependudukan Indonesia, 10(1), 53-64. https://doi.org/10.14203/jki.v10i1.57 
10. Hartati, I. (2020). Strategi Pembangunan SDM Kementerian Keuangan Republik Indonesia dalam Menghadapi Tantangan Era Disrupsi 4.0. Jurnal BPPK: Badan Pendidikan Dan Pelatihan Keuangan,13(1). 109-129. https://jurnal.bppk.kemenkeu.go.id/jurnalbppk/article/view/493

11. Malik, A. (2019). Creating competitive advantage through source basic capital strategic humanity in the industrial age 4.0. International Research Journal of Advanced Engineering and Science, 4(1), 209-215. https://doi.org/10.5281/zenodo.2588251

12. Marsudi, A.S., \& Widjaja, Y. (2019). Industri 4.0 Dan Dampaknya Terhadap Financial Technology Serta Kesiapan Tenaga Kerja Di Indonesia. Ikra-Ith Ekonomika, 2(2), 1-10. https://journals.upi-yai.ac.id/index.php/IKRAITH-EKONOMIKA/article/view/398

13. Mashadi, \& Irawan, S. (2017). Model Struktural Minat Mahasiswa Berkarir di Bidang Perbankan Syariah Sebagai Dasar Pengembangan Proses Pembelajaran. Jurnal Analisis Sistem Pendidikan Tinggi, 1(1), 1-10. https://doi.org/10.36339/jaspt.v1i1.19

14. Mekinjić, B. (2019). The impact of industry 4.0 on the transformation of the banking sector. Journal of contemporary economics, 1(1). https://doi.org/10.7251/JOCE1901006M

15. Otoritas Jasa Keuangan. (2019). Jumlah Bank Menurut Tingkatan dan Kelompok Bank. Otoritas Jasa Keuangan Provinsi Riau.

16. Zain, I., \& Akbar, Y.R. (2020). Bank dan Lembaga Keuangan Lainnya. Penerbit Deepublish. 